\title{
Supply Chain Material Management Framework In Assemble To Orders (ATO)
}

\author{
Irwana Abd Malek \\ Razak School of Engineering and Advance Technology, \\ University of Technology Malaysia, Johor, Malaysia \\ Email: irwana.malek@gmail.com (Corresponding Author) \\ Abdul Rahman Abdul Rahim \\ Razak School of Engineering and Advance Technology, \\ University of Technology Malaysia, Johor, Malaysia \\ Email: drabdrahman.66@gmail.com
}

\begin{abstract}
This study investigates and analyzes Critical Success Factors (CSFs) construct in Supply Chain implementation to minimize product lead-time and to identify the relationship between reducing raw material lead-time and improving product lead time. Short delivery lead time and efficient management on material inventories are two crucial elements that determine the competitiveness of many contract assembly manufacturers, especially in contract manufacturing. Assemble-to-Order (ATO) environment has become popular because companies do not want to keep finished goods inventories that lead to an increase in operational cost. ATO manufacturing involves production only upon receiving confirmed orders from customers. Thus, this study focuses on CSFs in Supply Chain Management (SCM) implementation and develops a comprehensive SCM framework for ATO contract manufacturing. Raw material lead time and material management process flow are the main concerns in the SCM context and ATO manufacturing environment. This study investigates elements to minimize the issues caused by the long product lead time and to identify the relationship between reducing raw material lead time and improving product lead time. Material classification, raw material improvement strategy, and suppliers' relationships are reviewed to develop and enhance current material strategy in accordance with present situations. An overall supplier material management system will be developed to improve the entire supply chain system as well as information sharing and identification methods. Information sharing from manufacturers to suppliers and vice versa is important to ensure that manufacturers can obtain scheduled and timely production information. Information from manufacturers to suppliers provides an advantage for the suppliers to prepare the raw materials and capacity plan to meet ATO requirements. The framework is unique as it addressed the importance of CSFs constructs, planning and monitoring processes to continue the success in SCM implementation. This framework integrates most of the planning process as the first input namely product classification, material management strategy, information sharing, logistic management and supplier relationship. This includes demand planning, supply planning, demand fulfillment, replenish planning and lead time planning. The planning process covered all demand and supply from customers, suppliers and manufacturers perspectives. The monitoring process in this framework is a guideline to companies on continuous SCM implementation.
\end{abstract}

Keywords: assemble-to-order (ATO), supply chain management (SCM), framework

\section{INTRODUCTION}

Short delivery lead time is one of the main factors in customer satisfaction. Challenges in supply chain management (SCM) and supply chain strategies cannot be addressed in isolation because they directly affect other chains such as a set of activities associated with new product introduction. The supply chain is a complex network of facilities dispersed over a large geographical area and in many cases, all over the world. Delays in product lead time to the customers is a major issue in SCM. The challenge of SCM for many organizations is to shorten the raw material lead times so that product lead times can be improved. Errors in sales forecasts compared with actual demand can affect raw material lead time, especially in assemble-to-order (ATO) industries where demand and requirements are unpredictable and inconsistent (Storey et al., 2006). The ATO concept has become a popular strategy for manufacturing firms that seek to be both responsive and cost efficient (Benjaafar and El Hafsi, 2006). Products with reduced delivery lead time and efficient inventory management are two crucial elements that determine the competitiveness of many contract assembly manufacturers, especially in the electronics industry (Hsu et al., 2006).

An important driver of the ATO system is the short product life cycle to minimize the risk of carrying high inventory (Zhao and David, 2006). Recently, supplying products to customers within a short delivery lead time with low inventory at the suppliers has been a crucial issue and requires good strategies for companies to sustain themselves in the market and to fulfill customers' requirements. The electronics industry is highly complex and its material management is difficult to control because of a large number of products and fast changes in the volume of components.

The complexity and difficulties in ATO companies require proper material management process in overall SCM activities. Lead time is not only related to product lead time but also include raw material availability, 
transportation, production, warehouse, material preparation, design and delivery. Erenguc et al., (1999) proposed an operational framework for addressing production and distribution problems in supply chains. With the advances in IT, there has been a shift of research focus on SCM in terms of framework, concept and model development (Samaranayake, 2002; Caprihan et al., 2001). This paper focus on the development of a framework to improve raw material lead time by developing material management strategy with consideration of CSFs in SCM activities and issues in case study companies. The framework is unique as it addressed the importance of CSFs constructs, planning and monitoring processes to continue the success in SCM implementation. This framework integrates most of the planning process as the first input and integrates most of CSFs constructs namely product classification, material management strategy, information sharing, logistic management and supplier relationship. The monitoring process in this framework is a guideline to companies on continuous SCM implementation.

Figure 1 shows a summary of customer fulfilment requirement dates in research companies. The results show that the average achievement of Company $\mathrm{X}$ is $40 \%$ and that of Company $\mathrm{Y}$ is $5 \%$. In this study, we focus on the development of a framework to improve raw material lead time by developing a material management strategy with consideration of critical success factors (CSFs) in SCM activities and issues in research companies.

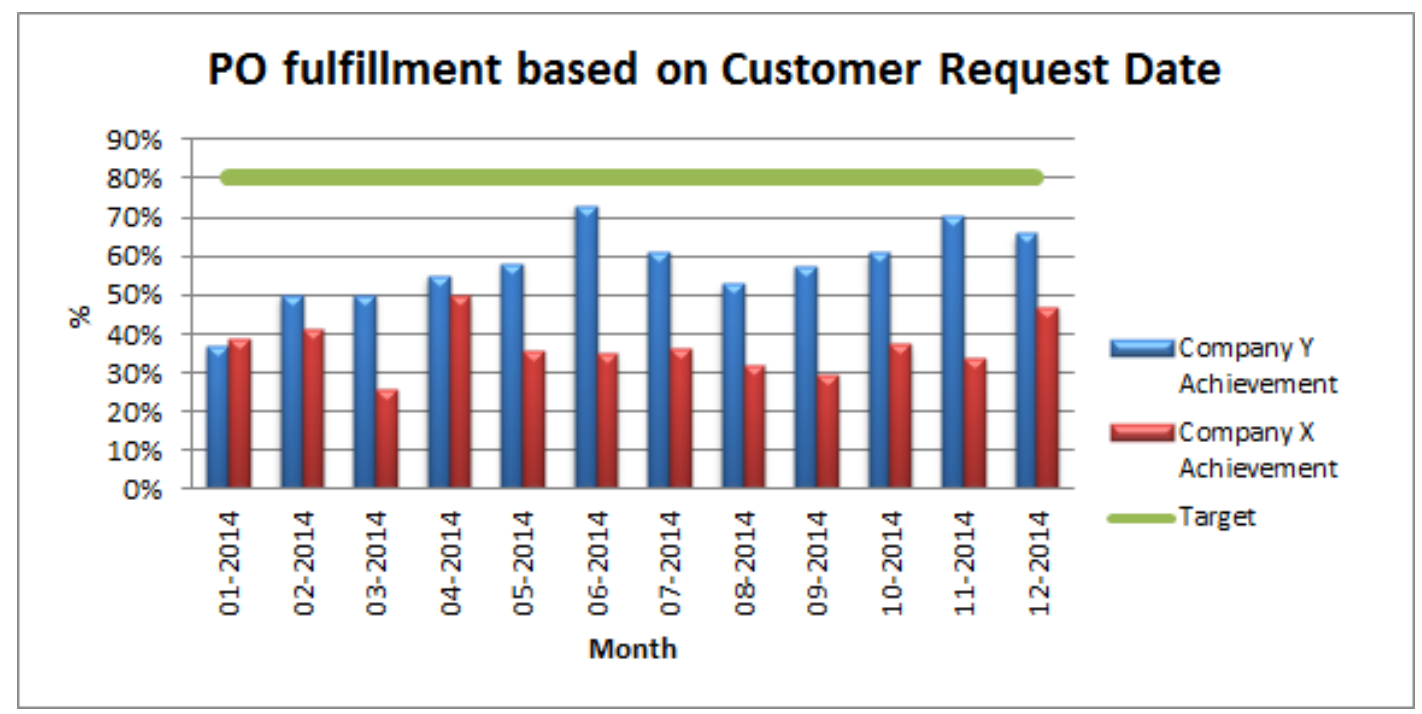

Figure 1 Purchase order fulfillment based on customer request date

\section{LITERATURE REVIEW}

SCM incorporates multiple processes and activities from suppliers to customers with a variety of business strategies to enhance value and satisfaction for customers (Soon et al., 2011; Chopra et al., 2001). SCM often refers to a process-oriented management approach to sourcing, producing, and delivering goods and services from supplier's supplier to customer's customer; these efforts include order management, distribution across all channels, and delivery to customers (Harland, 1996; Lummus et al., 2001 and Lamber, 2000). According to Sundram et al. (2011), Li et al. (2006), and Lyons et al. (2004), the shortterm objectives of SCM are enhancement of productivity and reduction of inventory and lead time, and its long-term objectives are to increase market share and to promote integration.

\subsection{Assemble-to-Order (ATO)}

Over the past decade, the ATO system has become a widely accepted business model in the electronics industry (Sun, 2006). The ATO concept is a strategy in which standard parts and subassemblies are acquired or manufactured in accordance to forecasts, while schedules for remaining components, subassemblies, and the final assembly are not executed until detailed product specifications have been derived from booked customers' orders (Elfving, 1999). Benjaafar (2006) supports the idea that ATO production enables a firm to shorten its response time to its customers by staging inventory of components ahead of demand while postponing the final assembly until the demand is fulfilled.

According to Song et al., (2003) and Hsu et al., (2006), the ATO system includes several components and several products in which the demand only comes from products while the system keeps the inventory at the component level. An ATO system is an efficient way to deliver a high level of product variety to customers while maintaining reasonable response times and low cost. Meanwhile, Murthy (1997) asserts that an ATO approach is used when the product market strategy pursues customization (i.e., offering a large number of potential end item configurations) by allowing customers to select a combination of features associated with several key product modules. However, ATO systems are notoriously difficult to analyze and manage, according to Benjaafar (2006). The difficulty appears to be due to factors such as (a) demand for various components being correlated, (b) supply lead times for different components, and (c) order fulfillment being dependent on the availability of multiple components.

These factors cause difficulty in managing components independently. According to Zhao et al., (2006), an important driver of ATO systems is short product life cycle, which substantially increases the risk of carrying inventories of the finished goods. ATO systems 
enable the manufacturers to provide customers with a large variety of products in a timely fashion without carrying expensive finished-goods inventories. According to Wei et al. (2006) and Bao (2010), the ATO system has become a widely accepted business model in the electronic industry because it is responsive and cost efficient. Many hightechnology firms that face increasing customer expectations, shrinking product life cycles, growing demand for product varieties, and rapid technological breakthroughs have successfully used ATO to broaden their customized product offerings, to lower inventory cost, and to reduce time to market. In response to increasing pressure from customers for fast delivery, mass customization, and decreasing life cycles of products, many high-tech firms have adopted the ATO system in place of the traditional make-to-stock (MTS) strategy in order to reduce the inventory (Agrawal et al., 2011).

\subsection{Critical Success Factors (CSFs)}

In this study, CSFs in SCM were identified to develop the framework. Mentzer et al. (2001) defined SCM as the systematic and strategic coordination of traditional business functions within a particular company and across businesses within the supply chain to improve the long-term performance of the individual companies and the supply chain as a whole. Numerous studies have investigated the CSF construct in SCM because of the complexity of SCM and the difficulties in turning concept into practice, making SCM more challenging to understand and implement (Talib et al., 2015; Ballou, 2007; Christopher, 2011). Based on the literature review of SCM, this study analyzes seven CSF constructs with the most significant effect on SCM implementation; these constructs are lead time, inventory management and product classification, material management strategy, information system, logistics, design change, and supplier relationship. Table 1 summarizes the $\mathrm{CSF}$ construct derived from the literature.

Table 1 Summary of CSF Constructs in SCM

\begin{tabular}{|c|c|c|c|}
\hline No. & CSF Constructs & Elements & Authors \\
\hline 1 & Lead Time & $\begin{array}{l}\text { Lead time becomes a competitive advantage as } \\
\text { a result of market demand. This construct } \\
\text { involves improving product and material lead } \\
\text { time to comply with and fulfill customer } \\
\text { requirements. }\end{array}$ & $\begin{array}{l}\text { Fang, et al. (2007); Tummala et al. (2006); Wong et al. } \\
\text { (2005); Arnheiter and Maleyoff (2005); Yang and Pan } \\
\text { (2004); Ouyang and Wu (1997); Tersine et al. (1995) }\end{array}$ \\
\hline 2 & $\begin{array}{l}\text { Inventory Management and } \\
\text { Product Classification }\end{array}$ & $\begin{array}{l}\text { Minimizing and managing inventory with } \\
\text { optimum stock, identifying materials with product } \\
\text { classification for urgent materials and high } \\
\text { demand }\end{array}$ & $\begin{array}{l}\text { van Kampen et al. (2012); Teunter et al. (2010); Boylan et } \\
\text { al. (2008); Wallin et al. (2006); Zhang et al. (2001); Silver } \\
\text { et al. (1998); }\end{array}$ \\
\hline 3 & Material Management Strategy & $\begin{array}{l}\text { Segregating materials based on strategic } \\
\text { relevance with business environment, identifying } \\
\text { materials with long lead time and short lead time } \\
\text { for strategic decision making }\end{array}$ & $\begin{array}{l}\text { Lee et al. (2014); Routroy et al. (2013); Claassen et al. } \\
\text { (2008); Handfield and McCormack (2008); Puschmann et } \\
\text { al. (2005); Carlton and Dana (2004); Chen et al., (2004); } \\
\text { Minner (2003); Blatherwick (1998); }\end{array}$ \\
\hline 4 & Information System & $\begin{array}{l}\text { Integrating between business strategy and } \\
\text { information system, improving efficiency and } \\
\text { effectiveness, ensuring accurate information, } \\
\text { reducing email and improving communication }\end{array}$ & $\begin{array}{l}\text { Patil et al. (2014); Shih et al. (2012); Wong et al. (2011); } \\
\text { Liao et al. (2011); Hutzschenreuter et al. (2010); Al- } \\
\text { Mutawah et al. (2009); Hult et al. (2007); Maqsood et al. } \\
\text { (2007); Carr and Kaynak (2007); Humphreys et al. (2004); } \\
\text { Leek et al. (2003); Power et al. (2001); Cachon et al. } \\
\text { (2000) }\end{array}$ \\
\hline 5 & Logistics & $\begin{array}{l}\text { Integrated logistics management system, } \\
\text { benchmarking logistics performance, and } \\
\text { maintaining logistics partnerships }\end{array}$ & $\begin{array}{l}\text { Talib et al. (2015); Koh et al. (2011); Thoo et al. (2011); } \\
\text { Lönngren et al. (2010); Walker et al. (2008); Lee (2008); } \\
\text { Fawcett (2008); Hidalgo et al. (2009); }\end{array}$ \\
\hline 6 & Design Change & $\begin{array}{l}\text { Controlling and monitoring product life cycle and } \\
\text { ensuring continuous improvement, changes are } \\
\text { made to meet customers' demand and } \\
\text { competitiveness in the market }\end{array}$ & $\begin{array}{l}\text { Stang Valand (2010); Marrewijk et al. (2010); Jelinek et al. } \\
\text { (2008);Bate (2007); Dunbar and Starbuck (2006); Kent } \\
\text { (2003); Romme (2003); Kidd et al. (2000); }\end{array}$ \\
\hline 7 & Suppliers' Relationships & $\begin{array}{l}\text { Sharing risks and rewards, maintaining } \\
\text { relationships to ensure positive impact on overall } \\
\text { SCM performance }\end{array}$ & $\begin{array}{l}\text { Bowersox et al. (2010); Chen et al. (2004); Kotabe et al. } \\
\text { (2003); Carr and Pearson (2002); Shin et al. (2000); De } \\
\text { Toni and Nassimbeni (1999); Lambert et al. (1998); }\end{array}$ \\
\hline
\end{tabular}




\section{METHODOLOGY}

To develop the SCM framework, this study presents a case study of two contract manufacturing companies. These companies were analyzed to obtain a full understanding of the nature of their business issues, as well as the precise functions of the suppliers. To limit the research scope within a specific area, this study focuses on suppliers and covers a limited number of scopes in supply chain material management. These aim is to develop a comprehensive SCM framework in ATO company for raw material lead time reduction from which the critical success factor (CSFs) were derived from literature. Research methods employed are participant observation and interview with six respondents from the two companies.

\subsection{Data Collection}

The research strategy employed in this study is based on qualitative approaches. The primary data are obtained from qualitative research that is conducted mainly based on participants' observation and interview sessions. In this study, the use of interview and participants' observation facilitates full participation of the respondents and it is easy to understand the respondents' feelings, experiences, opinion and perception regarding the related topics discussed. Primary data always recognized as valid, independent and trustworthy.

\subsection{Data Analysis}

Data analysis is conducted through participant observation, interviews, and document analysis. Data analysis using grounded theory technique involves three stages, namely, open coding, axial coding, and selective coding. In open coding, the data are categorized into units; in axial coding, the relationships between categories are identified; and in selective coding, the core categories are integrated to produce a theory (Strauss and Corbin, 1998). As regards the current study, the data obtained are analyzed by using the constant comparative method that is based on the grounded theory approach. The analysis process starts with transcribing, coding, and categorizing the data into different sets and then comparing them. Table 2 shows outputs from case study companies throughout participant observation, interviews, and CSFs identified from the literature.

Table 2 Summary of data analysis from company case studies through participant observation and interviews

\begin{tabular}{|c|c|c|c|}
\hline CSF construct & Elements & Actual practice in Company $X$ & Actual practice in Company $Y$ \\
\hline Lead time & $\begin{array}{l}\text { Ability to support urgent orders and an } \\
\text { upsurge of orders }\end{array}$ & $\begin{array}{l}\text { Current lead time for products is } \\
\text { more than } 90 \text { days. }\end{array}$ & $\begin{array}{l}\text { Approximately } 87 \text { percent of materials come } \\
\text { from overseas with long lead time. }\end{array}$ \\
\hline $\begin{array}{l}\text { Product } \\
\text { Classification }\end{array}$ & $\begin{array}{l}\text { Identifying and determining high and low } \\
\text { consumption in inventory management }\end{array}$ & $\begin{array}{l}\text { Absence of product classification } \\
\text { and end with high inventory } \\
\text { keeping }\end{array}$ & $\begin{array}{l}\text { Absence of product classification and end } \\
\text { with high inventory keeping }\end{array}$ \\
\hline $\begin{array}{l}\text { Material } \\
\text { Management } \\
\text { Strategy }\end{array}$ & $\begin{array}{l}\text { Material management to plan the inventory } \\
\text { and production to fulfill customer requirements }\end{array}$ & $\begin{array}{l}\text { Sales forecast, safety stock, MRP } \\
\text { process, and consignment stock }\end{array}$ & Sales forecast, buffer stock, and MRP \\
\hline $\begin{array}{l}\text { Information } \\
\text { System }\end{array}$ & $\begin{array}{l}\text { Effective communication tools to share the } \\
\text { information in a timely manner }\end{array}$ & Email & Email \\
\hline Logistics & $\begin{array}{l}\text { Ability to support any delivery to customers } \\
\text { and to import materials, timely provision of } \\
\text { shipping information }\end{array}$ & $\begin{array}{l}\text { Single source forwarder and } \\
\text { shipping information update in } \\
\text { database for easy reference }\end{array}$ & $\begin{array}{l}\text { Internal warehouse to keep materials and } \\
\text { manual handling of inbound and outbound } \\
\text { activities, creation of customer complaint } \\
\text { system }\end{array}$ \\
\hline Design Change & Change in design or formulation & $\begin{array}{l}\text { Controllable and stable design, } \\
\text { easy material preparation and } \\
\text { production schedule }\end{array}$ & $\begin{array}{l}\text { Uncontrollable because of substantial } \\
\text { changes in formulation, difficulty in material } \\
\text { and schedule arrangement }\end{array}$ \\
\hline $\begin{array}{l}\text { Supplier } \\
\text { Relationships }\end{array}$ & $\begin{array}{l}\text { Forming closer relationships with suppliers to } \\
\text { improve and discuss many aspects of strategy } \\
\text { formulation and day-to-day operations }\end{array}$ & $\begin{array}{l}\text { Maintenance strategy, operation } \\
\text { solution, performance monitoring, } \\
\text { and contract management }\end{array}$ & $\begin{array}{l}\text { Maintenance of strategy and contract } \\
\text { management }\end{array}$ \\
\hline
\end{tabular}




\section{RESULT AND DISCUSSION}

The major components of the proposed framework are based on current reviews of ATO contract manufacturing companies. The strengths of these frameworks are analyzed to determine the important issues in supply lead time that must be considered when implementing and managing materials, and to identify components that need to be incorporated into a new integrated framework. This study aims to develop a comprehensive SCM framework in an ATO company for raw material lead time improvement through a case study.
The material management framework is developed to improve the overall process, namely, SCM material management framework in Figure 2. These framework elements contain input data referred to as planning process, and to continue with the implementation (execution) and monitoring process. Using this framework, the company can identify suitable planning elements for their operation and an approach to start the implementation. To ensure effectiveness, a monitoring process is required and the framework proposes monitoring methods to evaluate the SCM strategy. Considering the monitoring process, the company can decide whether to continue or change its improvement method.

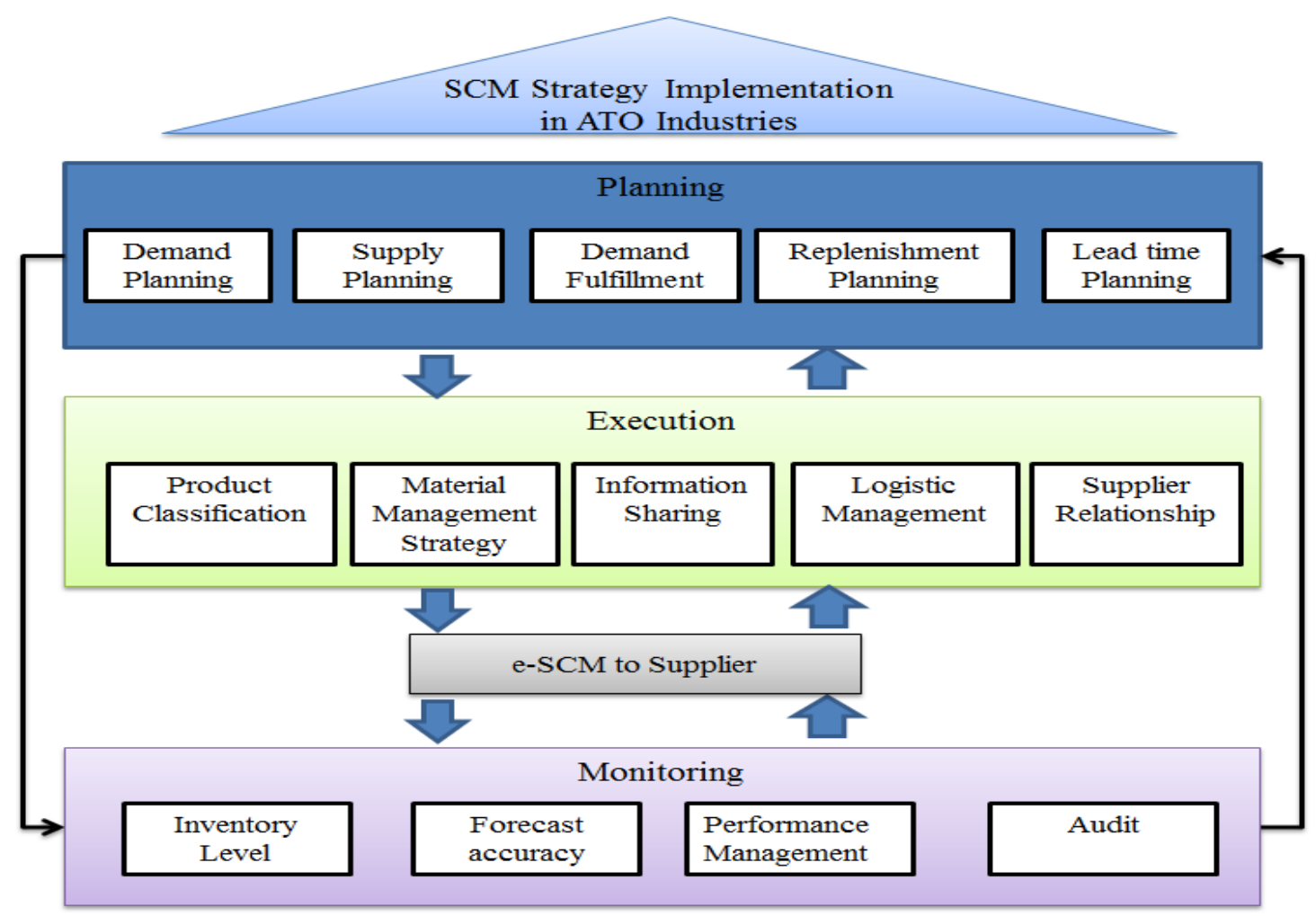

Figure 2 SCM Material Management Framework

\subsection{Planning Process}

The first feature of the SCM final framework is related to the planning process. The planning process in this framework refers to the input data and information required to update before proceeding with execution. The importance of the planning process in SCM implementation is to review and choose the strategies before proceeding with the action required for the next process. The planning process in this framework consists of demand planning, supply planning, demand fulfillment, replenishment planning, and lead time planning.

\subsubsection{Demand Planning}

Demand planning is a multi-step operational SCM process used to create reliable forecasting. Effective demand planning can guide users to improve the accuracy of revenue forecasts, aligning the inventory levels with peaks and troughs in demand, and enhancing the profitability of a given channel or product. In the corporate world, to meet customers' requirements, the integration of various business processes, such as demand planning and forecasting, procurement, manufacturing and assembly, distribution, and effective and efficient management of flow of resources from point of origin to point of destination, has become important aspects of SCM (Lummus et al.,, 1999; Mentzer et al., 2001; Sundram et al., 2011). Demand planning elements such as customer or market selection, forecasting, pricing strategy and order promising policies are part of the sales process. To succeed in lead time monitoring, companies have to review and identify demand from customers before proceeding to issue the material purchase order (PO) or production plan. Without proper review, the company will end up with high inventory, lead time issues, and storage and cash flow problems.

Accurate demand planning enables manufacturing to postpone production of anticipatory stock and can also result in shorter, more predictable order cycles. Guaranteed sales targets enable logistics and distribution managers to use storage and delivery resources effectively to reduce costs as well as to increase customer service by tailoring operations. For example, retail receiving departments may work closely with a manufacturer's shipping department to 
allow shipments to be loaded in the order in which products are needed, facilitating offloading and sorting time, and streamlining cycle times (Stank et al. 1999).

\subsubsection{Supply Planning}

Supply planning refers to the requirements and supply needs in a company, particularly from the suppliers. The contract manufacturers might need to decide on loading components prior to the actual order. This task entails commitment to achieve on-time delivery, especially when the procurement lead times for components are extended. At this point, the company needs to predict future requirements to balance supply and demand, which means that the company needs to determine the best practices to fulfill the requirement from the demand plan. From the demand plans based on sales forecast and sales orders, the company needs to predict the quantity of orders from suppliers based on the lead time. However, the future demand calculation should be decided and a review should be made on the effect of obsolescence and slow movement of inventory. Requirements without confirmed orders lead to obsolescence or slow movement, thereby causing cash flow and inventory issues.

\subsubsection{Demand Fulfillment}

Demand fulfillment refers to the percentage of orders that meets the delivery performance with complete and accurate documentation and absence of delivery damage to meet customers' requirements. Demand fulfillment involves generating, filling, delivering and servicing customer orders. To accomplish demand fulfillment, management must design a network and a fulfillment process that enables the firm to meet customers' requests while minimizing the total delivery cost (Keely, 2002). This task requires integration of logistics, marketing, finance, purchasing, research and development, production within the firm, and coordination with key suppliers and customers. At the operational level, the demand fulfillment process focuses on transactions, while at the strategic level, management can focus on making critical improvements to the process that influences the financial performance of the firm, its customers, and its suppliers. A streamlined process reduces the order-to-cash cycle, thereby freeing up capital and reducing the delivery lead time that allows for a reduction in inventory levels. Thus, order fulfillment can affect the financial performance of the focal firm, as well as that of other supply chain members. Consequently, the company has to define its strategy to fulfill customers' demand. This step is very important to increase customer satisfaction, thereby indirectly sustaining the market.

\subsubsection{Replenishment Planning}

The replenishment approach aims to meet consumers' demand and ensure that the stock is full again. Replenishment is typically triggered when the inventory levels hits the reorder point from the system setup. Replenishment planning focuses on having the right product in the right place at the right time. Effective replenishment planning requires a focus on the products, customers, and locations that have the most significant impact on company profitability. In this process, the company needs to define a review period for replenishment and ordering quantity. Then, it needs inventory parameters to determine whether an order for replenishment should be placed within the review time or not. This process aims to ensure that the company has sufficient material inventory to meet customer demands and demand planning. With replenishment planning, the company can easily consider the effects of inventory investment, service levels, and current orders and commitments.

The replenishment process setting depends on an organizational strategy and a business plan. Several options for the company to set up the replenishment method are the following:

i) Re-order point. This option is based on consumption and expected demand, which must be determined immediately through computation of consumption statistics, forecasts, or summarized gross requirements on an item level derived from production plans. Comparisons are made on the basis of stock transactions. Another is the periodic review system, which makes comparisons with stock inspections at predetermined constant intervals. If the quantity on hand is lower than the reference quantity, a replenishment process or order/refill process is initiated. With the periodic review system, the administration can be more efficient, and the ordering and transportation cost can be reduced because of opportunities to consolidate orders and deliveries (Jonsson, 2008). Another form of re-order point system is the two-bin system. When the first bin is consumed, a new order is initiated, and the other bin covers the needs until the first bin is replenished (Mattsson et al., 2003).

ii) Material requirement planning (MRP). This option is one of the most widely used principles in the industry. In principle, MRP is a method that relies on scheduling time for new deliveries according to calculations of when the net requirement occurs. Planning for materials that are used for the end product is calculated through the product structure (BOM). The start of this process is the production plan of the end products. The production plan consists of quantities and the time during which these quantities must be produced. Based on this information, material needs for raw materials and other purchased parts in the structure are calculated based on inventory on hand and already planned orders. The prerequisites for MRP are data consisting of production plans/anticipated demands, production structure, inventory on hand, lot- sizing principles, and lead times (Mattsson et al., 2003). These data are important in MRP and must be current and accurate for correct calculations (Kumar and Meade, 2002). All these data and calculations with MRP are handled through the companies' ERP system.

iii) Run-out time planning. This option is closely related to the re-order point method, but it uses a time expression instead of quantity. This could lead to a better understanding of how long a stock quantity will last and an improved ability to decide when ordering is necessary. Time period coverage describes the time during that the available quantity on hand is expected to cover; this period is calculated by dividing the available quantity on hand by expected demand per time unit (Mattsson et al., 2003). 
iv) Order-based planning. This option means that material flows are initiated by new orders directly corresponding to a customer order or a manufacturing order. When a new customer order is registered in the material planning system, a manufacturing or $\mathrm{PO}$ is automatically created for the corresponding manufacturing item and purchase item (Mattsson et al., 2003).

v) Kanban. This option is related to the re-order point method and is an uncomplicated method in which a visible card signal is needed for replenishment. To use Kanban, demand should be high and even, fluctuations in demand must be limited, and products should be fairly standardized. Kanban is clearly a pull method, which means that needs are directly initiated from a supply point only when materials are required as a result of consumption. Besides low levels of tied-up capital or control of tied-up capital, additional advantages of the Kanban pull system are shorter lead times, increased system efficiency, ease of control, lower costs, and higher customer satisfaction (Wan et al., 2008). However, the Kanban system is unsuitable for materials with long lead times; expensive and physically large components may be controlled with other principles.

The decision to implement a replenishment planning strategy depends on the material lead time, cost, supplier's location, warehouse space, inventory, consumption pattern, cash flow, and product life cycle. In practice, for materials with high and stable consumption, the organization can use the re-order point as a replenishment strategy.

\subsubsection{Lead Time Planning}

Lead time refers to the latency between the initiation or planning and execution of a process. SCM theory clearly addresses the limitations to improve demand chain performance through the transfer of demand information when lead times are long (Fisher, 1997; Heikkilä, 2002; Mason et al., 1999; Perry et al., 1999). Lead time is related to demand information transfer from the customer to manufacturer and the company's need to determine the approach that should be followed to improve supply chain performance. SCM has been defined as the integration of key business processes from the end user through original suppliers that provides products, services, and information that adds value for customers and other stakeholders (Lambert et al., 1998; Treville et al., 2004). From this framework, lead time for a company should be improved so that the company can proceed with the execution process to choose the suitable strategies according to the business environment. This process is explained in Section 2.

\subsection{Execution Process}

The execution process refers to the implementation strategy to improve the lead time and meet the planning process. In this framework, the execution process includes product classification strategy, material management strategy, information sharing strategy, logistic management and supplier relationship strategies that the company needs to consider in SCM implementation.

\subsubsection{Product Classification}

Product classification is a strategy in which the organization has to classify its product as either highly important or less important. This classification strategy is very important for an organization to focus on high consumption and stable products to prepare materials and comply with customer requirements within a short lead time. For products with low consumption, organizations have to choose a material management strategy that is suitable for controlling the inventory level. Organizations cannot apply the same strategy to high-consumption products because the strategy has an effect on the inventory level, thereby causing slow-moving inventory, expired materials, and cash flow issues as a result of holding the unnecessary inventory. The product classification is based on high consumption and cost. For materials with high cost, organizations have to decide on the material strategy to minimize the effects on cash flow.

\subsubsection{Material Management Strategy}

Material management strategy refers to the option to implement material management based on product classification and planning process. Some of the material strategies that the organization can apply in their operations are buffer with supplier (BWS), buffer raw material (BRM) with supplier, reserve order (RO), consignment stock (CS), safety stock (SS), material requirement planning (MRP), and other controls (CTL). However, the material management strategy selections have to consider supplier ability, capacity, contract lead time, consumption, and cost. BWS is material management at the supplier's location without company liability. This operation focuses on the supplier's common materials, and the organization issues the PO based on the contract lead time. The supplier keeps the safety stock based on forecast. In this strategy, the supplier provides immediate visibility of inventory status and allocation quantity to manufacturers. Meanwhile, for the BRM strategy, the supplier processes common materials and keeps them based on forecasts without manufacturer's liability. RO is the manufacturer's responsibility, and this strategy includes common materials and materials with high usage. Consignment stock is for high usage and high cost, which are based on ABC and XYZ classifications. Safety stock strategy for suppliers is unable to apply BWS, BRM, $\mathrm{RO}$, and consignment stock. For this operation, the manufacturer will set the safety stock in their system and issue the PO based on this requirement. However, the safety stock setting will be based on the result of product classification. Another strategy that the organization can implement is using MRP to issue the PO to suppliers based on system suggestions according to confirmed orders and forecasts. However, this strategy is applicable to materials with stable demand. Otherwise, this strategy causes slow movement and expiration of material. Finally, CTL can be used for materials that are categorized as either unique or obsolete. This strategy requires support from the sales department to agree to keep the materials as stock.

\subsubsection{Information Sharing}

Information sharing refers to the extent to which critical and proprietary information is communicated among supply chain members with regard to market, product, and customer information (Mentzer et al., 2001; Li et al., 2006). The design of information flow in supply 
chains has traditionally followed the physical flow along the chain (Lewis et al., 2004). In many cases, sub-optimal supply chain performance has been the result of poor information sharing. However, adopting advanced information systems, which enables efficient information sharing across supply chain phases and between supply chain members, may change the situation (Kaipia, 2009). Information sharing is very important in supply chain to obtain improved results, common understanding, fast response, and transparent information. The main objective of this framework for information sharing is that the manufacturer should provide the necessary information to the suppliers for their activities, and the supplier provides real data and transparent information to the supplier with immediate response. This approach enables the manufacturer to plan its production and reply to customer. In this framework, e-SCM is proposed, which includes ePO, e-Expedite, e-Delivery Reply, and e-Forecast. The ePO system means that the manufacturer creates the PO in the system and conducts daily interface with the supplier's server. Meanwhile, e-Expedite, which deals with purchasers at the manufacturer's location, updates the actual requirement date based on customer demand in the system and conducts daily interface with the supplier's server. For e-Delivery Reply, the supplier updates the PO delivery date in the system and conducts daily interface with the manufacturer's server; then, the purchaser updates planners on the status of their production plan. Forecast data is important for the planned schedule and capacity of the supplier. Meanwhile, e-Forecast can help the supplier to obtain the forecast data immediately with an interface to the supplier's server and process accordingly. In conclusion, information sharing under this framework proposal is a system that is set up for semi-autopilot between manufacturer and suppliers.

\subsubsection{Logistics Management}

Logistics is the part of the supply chain process that plans, implements, and controls the efficient forward and reverse flow and storage of goods, services, and related information between the point of origin and the point of consumption to meet customers' requirements. The objective of logistic management is to identify related components; in this framework, the identified elements are goods, vehicles, facilities, and infrastructure. The four related entities are (a) sourcing and distribution, (b) land use, (c) transportation, and (d) traffic. Logistics activities take place in facilities located in relation to an infrastructure. These facilities are supplied with products by means of transportation (Gunnar, 2006). Forward flow has been complemented with reverse flow, flow with storage, and goods not only with services but also with information. This condition makes the definition much more complete but at the same time more complex.

The goods that manufacturers produce have to be managed properly in a warehouse; thus, warehouse operation is an important part of logistics where products (raw materials, parts, goods-in-process, and finished goods) are stored in and between points of origin and points of consumption (Lambert et al., 1998). In addition to storage, the following two major operations are associated with warehousing: movement and information transfer. Vehicles include activities and processes in logistic management where products have to transfer to customers or from suppliers to manufacturers. Organizations have to manage the vehicles properly to send the products to customers and to meet customer demand. Furthermore, the manufacturer needs to liaise and coordinate with suppliers to arrange the materials according to the production plan date, which means that inbound and outbound transportation, door-todoor transportation service, and contract delivery need to be set up for smooth operation. Terminals are facilities in which load units are shifted between links in a transportation network (Gunnar, 2006). Examples of terminals are ports, crossing points of transport modes (e.g., between road and rail), and facilities specialized in fast throughput of load units that make cross-docking possible. Organizations can also choose to have third party logistics with good facilities, such as bar code scanners and information in Web servers.

\subsubsection{Supplier Relationship}

Supplier relationship management refers to the business process that provides the structure for how relationships with suppliers are developed and maintained. Benefits of cross functional, collaborative relationships with key suppliers is the ability to co-create value (Enz et al., 2012). In customer relationship management, close relationships are developed with a small subset of suppliers based on the value that they provide to the organization over time, and more traditional relationships are maintained with the others. Supplier relationship management in this framework proposes a good information sharing channel; maintains and improves strategy (project requirement and long-term development); operation solution to plan capacity planning, disaster recovery, problem solution and reporting, managing contracts properly, trust (people and relationships and supplier competency), and performance monitoring. Performance monitoring activities are very important to perform gap analysis and make decisions to continue or end contracts. Furthermore, performance monitoring aims to ensure market growth, customer satisfaction, and positive financial performance (Stuart et al., 2012).

\subsection{Monitoring}

The monitoring process helps an organization to identify gaps in provision, helps clarify aims and objectives, and helps validate new approaches if current practices are not effective. This process also helps the organization to decide on the supplier's contract and cash flow, and on the customer's demand improvement.

\subsubsection{Inventory Level}

Inventory and management of inventory are major concerns for firms that intend to survive and remain competitive in the marketplace (Wallin et al., 2006), and to minimize direct investments and indirect costs incurred in managing inventory (Chase et al., 2004; Wallin et al., 2006). The method and approaches to manage and monitor inventory levels are ERP, JIT, weekly or monthly stock reviews, and days inventory outstanding (DIO). Maintaining the inventory level of the organization is an indicator of whether the SCM activities being implemented are suitable or need to be improved. For example, if the 
DIO is more than 100 days, the organization needs to hold the inventory so that it can be depleted within 100 days, thereby causing cash flow issues or slow-moving materials.

\subsubsection{Performance Management}

Performance management aims to evaluate and monitor company performance and to identify the gaps for improvement activities. In this performance management, several approaches can be implemented, such as customer's KPI, supplier's KPI, sales data, production output, and customer's complaints. Considering the customer's KPI and customer's complaints reports, the organization can identify whether or not it complies with customer expectations and demand. Using the required information, the organization can analyze the issues and develop a strategy for improvement. The supplier's KPI helps the organization to identify whether the supplier is meeting business needs. Meanwhile, production output and sales data information are indicators of whether productivity is increasing or decreasing. The information is essential to measure the organization's performance. If the production volume is high but the sales volume is low, the organization has to review the implemented material strategy.

\subsubsection{Forecast Accuracy}

Sales forecast involves helping organizations to prepare the raw materials in advance to comply with customer requirements and to supply them to customers within a short lead time. However, inaccurate forecasts result in high inventory, slow-moving materials, logistic issues, and cash flow problems. Accurate forecast data can help organizations to identify unrealistic requirements and can provide feedback to customers or salespersons to help them decide on what to do with excess materials. Organizations can also identify products with low forecast accuracy so that they do not have to consider them in material preparation. This arrangement can help prevent the risk of having obsolete materials.

\subsubsection{Audit}

In this framework, the following types of audits were proposed: supplier's audit, customer's audit, and ISO audit. The supplier's audit is required to ensure that the suppliers comply with requirements as stipulated in the contract. Findings from the customer's audit can help organizations to develop a strategy to meet customer expectations. Audit activities can be performed either quarterly, half yearly, or yearly.

\subsection{Framework Implementation Output}

Company Y implemented the framework in year 2016 and the results are presented in Figure 3. The results show the improvement in the ability of the company to fulfill customer requirements from an average of $58 \%$ to $86 \%$. Meanwhile, Company $\mathrm{X}$ improved its success rate from a monthly average of $40 \%$ to $92 \%$.

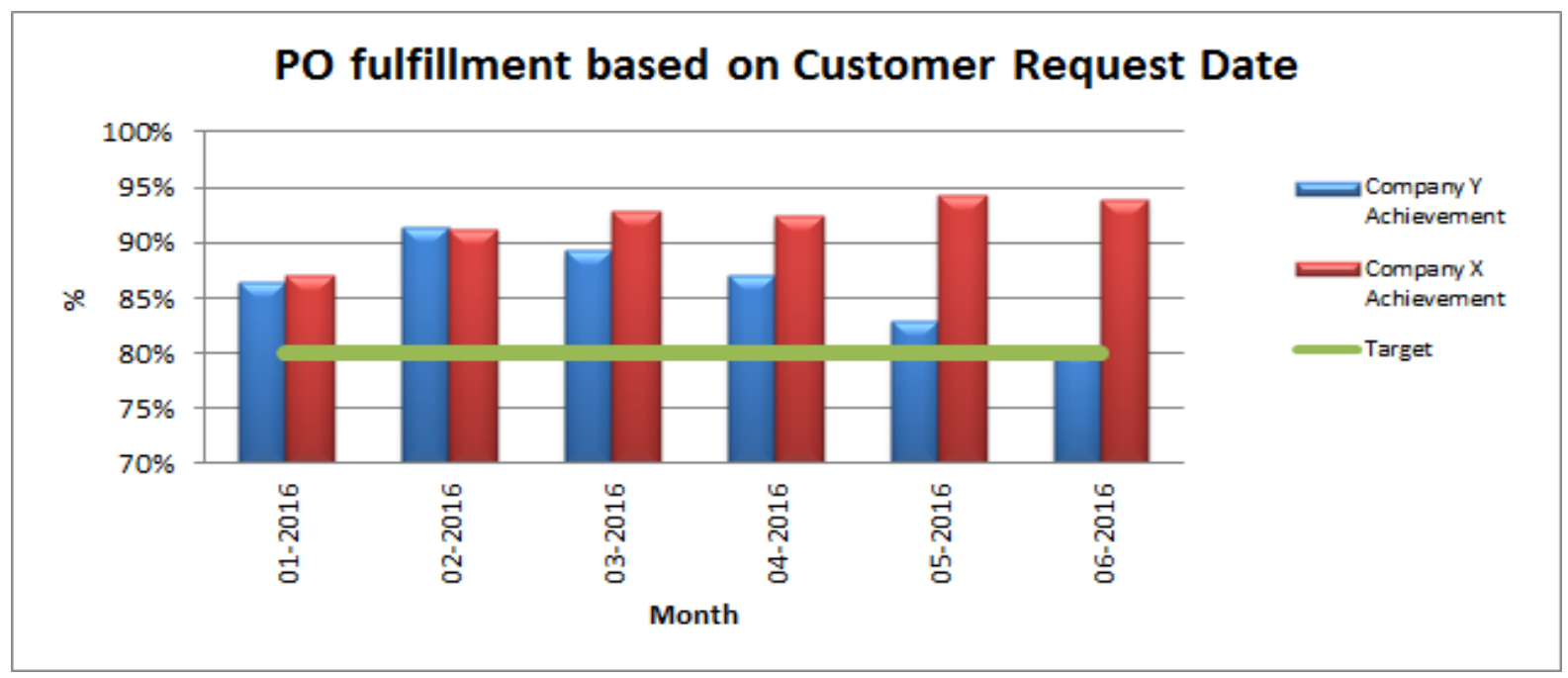

Figure 3 Framework Implementation Output

\section{SUMMARY}

This paper proposes a framework to improve the lead time by highlighting practical ways to assess both organizational efforts and results. The proposed framework integrates various components (materials, resources, approach, and product classification) involved in a business process across a number of partners in the supply chain. The framework development considered the contract manufacturing industry, which is characterized by high complexity in process, design, demand, and products. This framework study differs from others because it has multiple suppliers, both local and foreign, which experience different lead times and issues. In addition, this framework is capable of providing variability, flexibility, and maintainability for further improvement of supply chain activities. The main limitation of this work is a study based on ATO Company and a case study without empirical study consideration. The validity and the theoretical soundness of the conceptual framework of SCM can only be tested by data from real- life cases. Future research can be studied by developing the conceptual framework with empirical study. The validity can be tested with empirical study real life cases. This will be taken up as the future scope of the present work. 


\section{REFERENCES}

Agrawal, N., M. A. Cohen. (2001). Optimal Material Control in an Assembly System with Component Commonality. Naval Res. Logistic 48, pp. 409-429.

Al-Mutawah, K., Lee, V. and Cheung, Y. (2009). A New MultiAgent System Framework for Tacit Knowledge Management in Manufacturing Supply Chains. Journal of Intelligent Manufacturing 20 (5), pp. 593-610.

Arnheiter, E.D. and Maleyoff, J. (2005). The Integration Of Lean Management And Six Sigma, The TQM Magazine 17 (1), pp. 5-18.

Ballou, R.H. (2007). The Evolution and Future of Logistics and Supply Chain Management. European Business Review 19 (4), pp. 332-348.

Bao, Y.Y. and Xin, Z.H. (2010). Performance Analysis of ATO System with Impatient Waiting. IEEE 978 (1), pp. 42-44.

Bate, S.P. (2007). Bringing the Design Sciences to Organization Development and Change Management: Introduction To The Special Issue. Journal of Applied Behavioral Science 43, pp. 8-11.

Blatherwick, A. (1998). Vendor-Managed Inventory: Fashion Fad Or Important Supply Chain Strategy? Supply Chain Management: An International Journal 3, pp. 10-11.

Benjaafar, S., and ElHafsi, M., (2206). Production and Inventory Control of a Single Product Assemble-to-Order System with Multiple Customer Classes. Journal of Management Science 52 (12), pp. 1896-1912.

Boylan, J.E. and Syntetos, A.A. (2008). Forecasting for inventory management of service parts. In Kobbacy, K.A.H. and Murthy, D.N.P. (Eds), Complex System Maintenance Handbook (pp. 479-508). London: Springer-Verlag.

Bowersox, D. J., Closs, D. J., Cooper, M. B (2010). Supply Chain Management. McGraw-Hill International Edition.

Cachon, G. P., and Fisher, M. (2000). Supply Chain Inventory Management and the Value of Shared Information. Management Science 46 (8), pp. 1032-1048.

Carlton, D.W. and Dana, J.D. (2004). Product Variety and Demand Uncertainty, National Bureau of Economic Research Cambridge, MA.

Caprihan, R., Janardhan, R., Singh, J.P. and Anand, M. (2001), Simulation of supply chain networks: a review, paper presented at the 1st International Conference on Logistics and Supply Chain Management, PSG College of Technology, Coimbatore, 6-8 August.

Carr, A.S. and Kaynak, H. (2007). Communication Methods, Information Sharing, Supplier Development and Performance: An Empirical Study of Their Relationships. International Journal of Operations \& Production Management 27 (4), pp. 346-370.

Carr, A.S. and Pearson, J.N. (2002). The impact of purchasing and supplier involvement on strategic purchasing and its impact on firm's performance. International Journal of Operations \& Production Management 22 (9), pp. 1032-53.

Chase, R.B., Jacobs, F.R. and Aquilano, N.J. (2004). Operations Management for Competitive Advantage. (10th ed.) New York: McGraw-Hill, Irwin.

Chen, I.J and Paulraj, A. (2004). Understanding Supply Chain Management: Critical Research and a Theoretical Framework. International Journal of Production Research 42 (1), pp.131-163.

Choi, T., Dooley, K., Rungtusanatham, M. (2001). Conceptual Note: Supply Networks And Complex Adaptive Systems: Control Versus Emergence. Journal of Operations Management 19 (3), pp. 351-366.

Chopra, S. and Meindl, P. (2001). Supply Chain Management, Strategy, Planning and Operation, Prentice-Hall, Upper Saddle River, NJ.

Christopher, M. (2011). Logistics and Supply Chain Management. Singapore: FT Press.
Claassen, M.J.T., Weele, A.J.v. and Raaij, E.M.v. (2008) Performance outcomes and success factors of vendor managed inventory (VMI). Supply Chain Management: An International Journal 13 (6), pp. 406-14.

De Toni, A. and Nassimbeni, G. (1999). Buyer-Supplier Operational Practices, Sourcing Policies and Plant Performance: Result of An Empirical Research. International Journal of Production Research 37, pp. 597-619.

De Treville, S., Shapiro, R.D. and Hameri, A. (2004). From supply chain to demand chain: the role of lead time reduction in improving demand chain performance. Journal of Operations Management 21 (6), pp. 613-27.

Dunbar, R. and Starbuck, W. (2006). Learning To Design Organizations And Learning From Designing Them. Organization Science 17 (2), pp. 171-178

Elfving, J.A. (1999). Exploration of Opportunities to Reduce Lead Times for Engineered-to-Order Products, Doctor of Philosophy, University Of California, Berkeley.

Enz, M.G. and Lambert, D.M. (2012). Using Cross Functional, Cross Firm Teams To Co-Create Value: The Role Of Financial Measures. Industrial Marketing Management 41 (3), pp. 495-507.

Erenguc, S.S., Simpson, N.C. and Vakharia, A.J. (1999). Integrated production/distribution planning in supply chains: an invited review. European Journal of Operational Research 115 (2), pp. 219-36.

Ervolina, T., and Brenda. D. (2001). Moving Toward Dynamic Available to Promise. Management Science. 41, pp. 43-57.

Fang, X., So, K.C and Wang, Y. (2007). Component Procurement Strategies in Decentralized Assemble-to-Order Systems with Time-Dependent Pricing. Management Science 54 (12), pp. 1997-2011

Fawcett, S. E., Magnan, G. M., McCarter, M. W (2008). Benefits, Barriers, and Bridges to Effective Supply Chain Management. Supply Chain Management: An International Journal 13 (1), 35-48.

Fisher,M.L., (1997). What Is The Right Supply Chain For Your Product? Harvard Business Review, 75 (2), pp. 105-116.

Gunnar, S. (2006). Collaborative Logistics Management and The Role Of Third-Party Service Providers. International Journal of Physical Distribution \& Logistics Management. 36 (2), pp. 76-92.

Gupta, A. and Maranas, C.D. (2003). Managing Demand Uncertainty In Supply Chain Planning. Computers \& Chemical Engineering, 27 (8-9), pp. 1219-1227.

Handfield, R.B. and McCormack, K. (2008). Supply Chain Risk Management: Minimizing Disruptions in Global Sourcing. Boca Raton, FL: Auerbach Publications.

Harland, C. (1996). Supply Network Strategies - The Case of Health Supplies. European Journal of Purchasing and Supply Management 2 (4), pp. 183-92.

Heikkilä, J., (2002). From supply to demand chain management: efficiency and customer satisfaction. Journal of Operations Management 20 (6), pp. 747-767.

Hidalgo, A., López, V. (2009). Drivers and Impacts of ICT Adoption on Transport and Logistics Services. Asian Journal of Technology Innovation 17 (2), pp. 27-47.

Hsu, V.N., Lee C.Y and So, K.C. (2006). Optimal Component Stocking Policy for Assemble-to-Order Systems with LeadTime-Dependent Component and Product Pricing. Management Science 52 (3), pp. 337-351.

Hult, G.T.M., Ketchen, D.J., and Arrfelt, M. (2007). Strategic Supply Chain Management: Improving Performance through a Culture of Competitiveness and Knowledge Development Strategic Management Journal 28 (10), pp. 1035-1052.

Humphreys, P.K., Li, W.L., and Chan, L.Y. (2004). The Impact of Supplier Development on Buyer-Supplier Performance. The International Journal of Management Science 32 (2), pp. 131-143. 
Hutzschenreuter, T. and Horstkotte, J. (2010). Knowledge Transfer to Partners: A Firm Level Perspective. Journal of Knowledge Management 14 (3), pp. 428-448.

Jelinek, M., Romme, A.G. and Boland, R.J. (2008). Special Issue on Design Studies. Organisation Studies 29 (3), pp. 317-329.

Jonsson, P. (2008). Logistics and Supply Chain Management. Maidenhead, UK: McGraw-Hill.

Kaipia, R. (2009). Coordinating Material And Information Flows With Supply Chain Planning. The International Journal of Logistics Management 20 (1), pp. 144-162.

Keely L. C., (2002). The Order Fulfillment Process. The International Journal of Logistics Management 14 (1), pp. 19-32.

Kent, T. (2003). 2D23D: Management and Design Perspectives on Retail Branding International. Journal of Retail \& Distribution Management 31 (3), pp. 131-42.

Kidd, M W. and Thompson, G. (2000). Engineering Design Change Management. Integrated Manufacturing Systems 11 (1), pp. 74-77.

Koh, S. L., Gunasekaran, A., Goodman, T. (2011). Drivers, Barriers and Critical Success Factors for ERPII Implementation in Supply Chains: A Critical Analysis. The Journal of Strategic Information Systems 20 (4), pp. 385-402.

Kotabe, M., Martin, X. and Domoto, H., (2003). Gaining From Vertical Partnerships: Knowledge Transfer, Relationship Duration, and Supplier Performance Improvement in the U.S. and Japanese Automotive Industries. Strategic Management Journal 24 (4), pp. 293-316.

Kumar, S. and Meade, D. (2002). Has MRP Run Its Course? A Review of Contemporary Developments in Planning Systems. Industrial Management \& Data Systems 102 (8), pp. 453-462.

Lambert, D.M., and Cooper, M.C. (2000). Issues in Supply Chain Management. Industrial Marketing Management. 29, pp. 6583.

Lambert, D.M and Schwieterman, M.A. (2012). Supplier Relationship Management as A Macro Business Process. Supply Chain Management: An International Journal 17 (3), pp. 337-352.

Lambert, D. M., Cooper, M. C., Pagh, J. D (1998). Supply Chain Management: Implementation Issues and Research Opportunities. The International Journal of Logistics Management 9 (2), pp. 1-20.

Lee, H. (2004). The Triple-A Supply Chain. Harvard Business Review. 82 (10), pp. 102-113.

Lee, C.K.M., Lin, D., and Pasari, R. (2014). Strategic Procurement from Forward Contract and Spot Market. Industrial Management \& Data Systems 114 (5), pp. 778-796.

Leek, S., Turnbull, P.W. and Naude, P. (2003). How Is Information Technology Affecting Business Relationships? Results from A UK Survey. Industrial Marketing Management 32, pp. 119-126.

Lee, S. Y. (2008). Drivers for the Participation of Small and Medium-sized Suppliers in Green Supply Chain Initiatives. Supply Chain Management: An International Journal 13 (3), pp. 185-198.

Lewis, I. and Talalayevsky, A. (2004). Improving the InterOrganisational Supply Chain Through Optimization Of Information Flows. The Journal of Enterprise Information Management 17 (3), pp. 229-37

Li, G., Lin, Y., Wang, S. and Yan, H. (2006). Enhancing Agility By Timely Sharing Of Supply Information. Supply Chain Management: An International Journal 11 (5), pp. 425-35.

Liao, K., Ma, Z., Lee, J.J.-Y., and Ke, K. (2011). Achieving Mass Customization through Trust-Driven Information Sharing Between Buyer and Supplier: A Supplier Perspective. Management Research Review 34 (5), pp. 1-17.

Lönngren, H-M., Rosenkranz, C., Kolbe, H. (2010). Aggregated Construction Supply Chains: Success Factors in
Implementation of Strategic Partnerships. Supply Chain Management: An International Journal 15 (5), pp. 404-411.

Lummus, R., Krumwiede, D.W. and Vokurka, R.J. (2001). The Relationship Of Logistics To Supply Chain Management: Developing A Common Industry Definition. Industrial Management \& Data Systems 101 (8), pp. 426-3.

Lummus, R.R. and Vokurka, R.J. (1999), Defining Supply Chain Management: A Historical Perspective And Practical Guidelines. Industrial Management \& Data Systems 99 (1), pp. 11-17.

Lyons, A., Coleman, J., Kehoe, D. and Coronado, A. (2004). Performance observation and analysis of an information reengineered supply chain: a case study of an automotive firm. Industrial Management \& Data Systems 104 (8), pp. 658-66.

Marrewijk, A., Veenswijk, M., and Clegg, S. (2010). Organizing reflexivity in designed change: the ethnoventionist approach. Journal of Organizational Change Management 23 (3), pp. 212-229.

Mason-Jones, R., and Towill, D.R., (1999). Total cycle time compression and the agile supply chain. International Journal of Production Economics 62 (1-2), 61-73.

Maqsood, T. and Finegan, D.W.A. (2007). Extending The 'Knowledge Advantage': Creating Learning Chains. The Learning Organization 14 (2), pp. 123-141.

Mattsson, S. A. and Jonsson, P. (2003). Productions logistic, Studentlitteratur: Lund.

Mentzer, J.T. DeWitt, W., Keebler, J.S., Min, S., Nix, N.W., Smith, C.D. and Zacharia, Z.G. (2001). Defining Supply Chain Management. Journal of Business Logistics 22 (2), pp. $1-25$.

Minner, S. (2003). Multiple-supplier inventory models in supply chain management: A review. International Journal of Production Economics 81 (82), pp. 265-279.

Murthy, N.N (1997). The Manufacturing, Marketing, And Design Interface: Implications For Manufacturing Planning And Control In An Assemble-To-Order Environment, Doctor of Philosophy, The Ohio State University.

Ouyang, L. Y. and Wu, K. S., (1997). Mixture Inventory Model Involving Variable Lead Time with a Service Level Constraint. Computers \& Operations Research 24, pp. 875882.

Patil, S.K. and Kant, R. (2014). Knowledge Management Adoption in Supply Chain. Journal of Modelling in Management 9 (2), pp. 160-178.

Perry, M., Sohal, A.S., Rumpf, P., (1999). Quick Response supply chain alliances in the Australian textiles, clothing, and footwear industry. International Journal of Production Economics 62 (1-2), pp. 119-132.

Power, D.J., Sohal, A.S. and Rahman, S.U. (2001). Critical Success Factors In Agile Supply Chain Management-An Empirical Study. International Journal of Physical Distribution \& Logistics Management 31 (4), pp. 247-265.

Puschmann, T. and Alt, R. (2005). Successful Use of EProcurement In Supply Chains. Supply Chain Management: An International Journal, 10 (2), pp. 122-33.

Romme, A.G.L. (2003). Making A Difference: Organization As Design. Organization Science 14 (5), pp. 558-73.

Routroy, S. and Pradhan, S.K. (2013). Evaluating The Critical Success Factors Of Supplier Development: A Case Study. International Journal of Benchmarking 20 (3), pp. 322-341.

Samaranayake, P. (2002). Supply chain management: basis of a conceptual framework, paper presented at the 12th International Conference on Flexible Automation \& Intelligent Manufacturing, Dresden.

Samaranayake, P. (2005). A Conceptual Framework For Supply Chain Management: A Structural Integration. Supply Chain Management : An International Journal 10 (1), pp. 47-59. 
Shih, S.C., Hsu, S., Zhu, Z. and Balasubramanian, S. (2012). Knowledge sharing-a key role in the downstream supply chain. Information \& Management 49 (2), pp. 70-80.

Shin, H., Collier, D.A.and Wilson, D. D., (2000). Supply Management Orientation and Supplier/Buyer Performance. Journal of Operations Management 18, pp. 317-333.

Silver, E.A., Pyke, D.F. and Peterson, R. (1998). Inventory Management and Production Planning and Scheduling. New York, NY: Wiley.

Stuart, I.F, Verville, J. and Taskin, N. (2012). Trust in buyersupplier relationships. Journal of Enterprise Information Management 25 (4), pp. 392-412.

Storey, J. and Emberson, C. (2006). Supply chain management: theory, practice and future challenges. International Journal of Operations and Production Management 26 (7), pp. 754-774.

Song, J. S., and Zipkin, P. (2003). Supply Chain Operations: Assemble-To Order System. Research and Management Science 11, pp. 561-596.

Soon, Q.H, and Udin, Z (2011). Supply Chain Management from the Perspective of Value Chain Flexibility: An Exploratory Study. Journal of Manufacturing Technology Management 22 (4), pp. 506-526.

Stang Valand, M. (2010). What We Talk About When We Talk About Space: End User Participation Between Processes Of Organizational And Architectural Design. Ph.D Thesis, Copenhagen Business School, Denmark.

Stank, T.P., P.J. Daugherty and C.W. Autry (1999). Collaborative Planning: Supporting Automatic Replenishment Programs. Supply Chain Management 4 (2), pp. 75-85.

Sun, X., Wei, J., and Tu, F. (2006). Inventory Management in Assemble-to-Order System with Two Correlated Products. IEEE 1, pp. 810-814.

Sundram, V.P.K., Abdul Razak, I., Govindaraju V.G.R. (2011). Supply Chain Management Practices in the Electronics Industry in Malaysia: Consequences for Supply Chain Performance. An International Journal 18 (6), pp. 834-855.

Talib, Ab.M., Abdul Hamid A.B. and Zulfakar M.H. (2015). Halal supply chain critical success factors: a literature review. Journal of Islamic Marketing 6 (1), pp. 44-71.

Tersine, R.J. and Hummingbird, E.A. (1995). Lead-Time Reduction: The Search For Competitive Advantage. International Journal of Operations \&Production Management 15 (2), pp. 8-18.

Teunter, R.H., Babai, M.Z. and Syntetos, A.A. (2010). ABC Classification: Service Levels and Inventory Costs. Production and Operations and Management 19 (3), pp. 343-52.

Thoo, A. C., Huam, H. T., Yusoff, R. M., Rasli, A. M., Hamid, A. B. A. (2011). Supply Chain Management: Success Factors from the Malaysian Manufacturer's Perspective. African Journal of Business Management 5 (17), pp. 7240-7247.
Treville, D. S., Shapiro, R.D. and Hameri, A. (2004). From supply chain to demand chain: the role of lead time reduction in improving demand chain performance. Journal of Operations Management 21 (6), pp. 613-27.

Tummala, V.M.R., Phillips, C.L.M. and Johnson, M. (2006). Assessing Supply Chain Management Success Factors: A Case Study. Supply Chain Management: An International Journal 11 (2), pp. 179-192.

Van Kampen, T.J., Akkerman, R. and Pieter van D. (2012). SKU Classification: A Literature Review And Conceptual Framework. International Journal of Operations \& Production Management 32 (7), pp. 850-876.

Walker, H., Di Sisto, L., McBain, D (2008). Drivers and Barriers to Environmental Supply Chain Management Practices: Lessons from the Public and Private Sectors. Journal of Purchasing and Supply Management 14 (1), pp. 69-85.

Wallin, C., Rungtusanatham, M. J., and Rabinovich, E. (2006). What Is The "Right" Inventory Management Approach For A Purchased Item?. International Journal of Operations \& Production Management 26 (1), pp. 50-68.

Wan, H. and Chen F. (2008). A Web-Based Kanban System For Job Dispatching, Tracking And Performance Monitoring. International Journal of Advanced Manufacturing Technology 38, pp. 995-1005.

Wei, J., Sun, X and Tu, F. (2006 ). Inventory Management in Assemble-to-Order System with Two Correlated Products, IEEE $1, \mathrm{pp} .810-814$

Wong, C.Y., Arlbjorn, J.S. and Johansen, J. (2005). Supply Chain Management Practices in Toy Supply Chains. Supply Chain Management: An International Journal 10 (5), pp. 367-378.

Wong, W.P. and Wong, P.S. (2011). Supply Chain Management, Knowledge Management Capability, and Their Linkages Towards Firm Performance. Business Process Management Journal 17 (6), pp. 940-964.

Yang, J.S and Pan J.C. (2004). Just-In-Time Purchasing: An Integrated Inventory Model Involving Deterministic Variable Lead Time And Quality Improvement Investment. International Journal of Production Research 42 (5), pp. 853863.

Zhao, Y and David, S.L. D. (2006). Performance Analysis and Evaluation of Assemble-to-Order Systems with Stochastic Sequential Lead Times. Operation Research 54 (4), pp. 706724.

Zhao, Y and Simchi-Levi, D. (2006). Performance Analysis and Evaluation of Assemble-to-Order Systems with Stochastic Sequential Lead Times. Operation Research 54 (4), pp. 706724.

Zhang, R.Q., Hopp, W.J. and Supatgiat, C. (2001). Spreadsheet Implementable Inventory Control For a Distribution Center. Journal of Heuristics 7 (2), pp. 185-203.

Irwana Abd Malek received the Bachelor degree and Master degree from Universiti Teknologi Malaysia. Currently, she is a Ph.D. student in the Razak School of Engineering and Advance Technology, University of Technology Malaysia and a Head of SCM in multinational manufacturing industry. She has 17 years' experience in manufacturing, operations and supply chain management. Research in supply chain management, specifically inventory models and material management process, is her main interest.

Dr. Abdul Rahman Abdul Rahim is an Associate Professor and Director of UTM International and formerly was the Head of Engineering Department, UTM Razak School of Engineering and Advanced Technology, UTM Kuala Lumpur. He is an associate lecturer at Meiji University Japan since 2011. Prior to joining UTM he has worked with two multi-national corporations in the area of manufacturing. He graduated with a B.Sc. in Mechanical Engineering and B.Sc. in Engineering Management from University of Evansville (USA) in 1988. He obtained his MSc in Manufacturing Systems Engineering from Warwick University (United Kingdom) in 1991 and his PhD from Universiti Teknologi Malaysia in 2006. He also received a Certificate in Occupational Safety and Health in Manufacturing Industries from Worksafe Western Australia in 1998 as well as Train the Trainers Certificate for Safety and Officer Program from NIOSH, Malaysia. His research interest is in supply chain management, lean manufacturing and productivity improvement. 